\section{ROYAL COLLEGE OF SURGEONS.}

The following gentlemen were admitted on the 30th ult.:-Joseph Fenn Allnutt, Australia; Henry Adye, Bradford, Wiltshire; Barnabus Barrett, Shrewsbury; Joseph Lewis, Cardiff, Glamorganshire ; Edwin Moore, Highgate; George Puckle, Camberwell ; James Lewis Sanders, Chelsea; Charles Taylor, Nottingham; Leonard, Keatley Yelf, Ryde, Isle of Wight.

The following gentlemen were admitted on the 2nd instant :-Frank Lane Bindley, Burton-on-Trent, Staffordshire; Thomas Coghlan, Cork ; John Coogan, Cork; William Henry Cufaude, Acle, Norwich ; Walter Humphries, Cork ; Samuel Job, Bawtry, Yorkshire ; William Lichfield, Southampton; Joseph Beauchamp Matthews, Weston-on-the-Green, Oxon; Thadeus Leyden Molony, Ennistymon, co. Clare; Daniel Hack Tuke, York.

The following gentlemen were admitted on the 4th instant :-John Edmunds, Bangor-Iscoed, Flintshire; Joshua Lever, Bolton-le-Moors, Lancashire; John Noble, York ; George Bell Poppelwell, North Shields, Northumberland; Lewis Robert Ramond, Lower Sydenham, Kent; Richard Patrick Burke Taaffe, London; Frederick Edmund West, Dublin.

The following gentlemen were admitted on the 6th instant:-Thomas Bray, Dublin; Garret Butler, Dublin; Henry Richard Foquett, Lucknow, Bengal; James Hurd Keeling, Edinhurgh; Robert Leys, Banchory, Kincardineshire; Charles Benjamin Mosse, Carlow; Malim Sharman, Birmingham ; John Mortlock Tronson, Dublin.

The following gentlemen were admitted on the 9th instant:-Walter Bernard, Cork; Hallam Moore Dixon, Cape of Good Hope; William Archibald Garrington, Portsea; Alexander Robert Hudson, Fermanagh, Enniskillen; George Lawson, Forest Hill, Sydenham; James Henry Lewis, Kinsale, co. Cork ; William O'Connor, Munster; Edward Tenison Ryan, New York; Henry William Spry, Trinidad Place, Islington.

The Fellowship.-The following gentlemen were admitted to the Fellowship on the 10th inst:-Peter Hinckes Bird, Spring Gardens, diploma of membership dated May 19, 1848; Cornelius Black, Chesterfield, May 3, 1844; Archibald Prentice Childs, Bungay, August 10, 1849; Harvey Ludlow, Paternoster Row, June 22, 1849; William Scovell Savory, Charterhouse Square, Dec. 8, 1847.

\section{SOCIETY APOTHECARIES.}

Gentlemen admitted members on the 29th July:Matthew Corner, Whitby, Yorkshire; Charles Thick Eves, Cheltenham : Noah Fox, Nottingham; Augustus Brabius Webb Greatrex, Eccleshall ; Charles Hooper, Buntingford, Herts; Fredererick Francis Ormond, Plymouth; George Simpson, India; John Cuthbert Whaley, Kilburn.

Gentlemen admitted members on the 5th August:Edward Hare Bromley, Rippingale; William Adcock Burrows; Charles Moore Jessop, Bilton Hall, Yorkshire; William Edward Robbs, Grantham; Henry Little Sequeira, London.

\section{UNIVERSITY AND KING'S COLLEGE, ABERDEEN.}

At the August graduation at this University, the degree of M.D., was conferred on the following gentlemen, who were examined in the various branches of medicine, and found duly qualified :-John Morgan Bryan, Northampton; Thomas Collins, Aberdeen; Charles Henry Dunhill, London; John Boon Hayes,
Birmingham; William Aston Lewis, London; Peter William Long, Ireland; Thomas Morris, London ; James Orwin, Salop; James Hollins Pickford, Brighton; William Callender Tidy, London; Daniel Henry George Wildbore, London; James Goodehild Wakley, London:

$\overline{\text { OBITUARY. }} \frac{\text { S़े }}{\text { 음 }}$

July 27, aged 63, Erasmus L. 'Devonald, Esq., $\frac{\overline{\bar{c}}}{\bar{c}}$ surgeon, of 71 , Great Tichfield Street, and 6, Howey Place, London.

August 6, at Wooton-under-Edge, Robert Bailey, 00 Esq., surgeon, aged 74.

August 8, at his residence, Pucklechurch, Gloucester $-\overrightarrow{0}$ shire, aged 66, John Champeny Swayne, Esq., M.R.C.S.; late of Berkeley Square, Bristol.

August 3rd, at Brighton, after a severe illness, $\omega$ Richard Ebsworth, Esq., surgeon, of Shillingford, ino the 42nd year of his age.

\section{PROVINCIAL MEDICAL AND SURGICAL} ASSOCIATION.

NOTICE TO MEMBERS.

In addition to the names published in the last Journal as being appointed of the Council, that of Wm. Matrerson, jun., Esq., Local Secretary for $D$ Yorkshire, was accidently omitted.

W. P. Brookes, Esq., was also appointed Localó Secretary for Cheltenham, and

Eluis Jones, Esq., Local Secretary for Liverpoof In consequence of the great accession of new membs during the present year, the first eight numbers of the volume now in course of publication are out of print.

\section{J. P. SHEPPARD.}

Worcester, August 17th, 1852.

Secretary.

\section{ERRATA.}

In our report of the Anniversary Meeting, at page 404, column 2, line 14, the following correction is required:-For " read by the House Surgeon, Mr. Hussey," read-“read by E. L. Hussey, Esq., F.R.C.S.E., one of the Surgeons to the Infirmary." The paper consisted of a statistical account of all operations performed in that (the Radcliffe) Infirmary for. some years past.

The following error also occurred in Dr. Whiting's speech, in proposing a vote of thanks to Dr. Wilkinson, 을 after the reading of the Address in Medicine :-Page 404, col. 1, line 9, for " philosophical lectures," read $N$ "physiological lectures;" line 11, for "the general thanks of the town," read "the thanks of many in theo town."

\section{TO CORRESPONDENTS.} $-1$

Communications have been received from Dr. Oke, Mr. Martin, Dr. McWilliams, Justice to Worcester, Mr.응 King, University of London, Publicus, Mr. Paul, Nil Desperandum, Dr. Whiting, Dr. Garstang, Mr.? Harricks, Mr. Roe.

It is requested that all letters and communications con- $-\bar{O}$ nected with the Editorial department be sent to J. H. Walsh, Esq., Foregate Street, Worcester. Parcels and books for review may be addressed to the care of Mr. Churchill, Princes Street, Soho. 